\title{
Theophylline Reduces the Activity of Cerebroside- Sulfotransferase, a Key Enzyme in Myelination, in Cell Cultures from Newborn Mouse Brain ${ }^{1}$
}

\author{
HANS PETER SIEGRIST, ${ }^{(23)}$ THOMAS BURKART, KAREL HOFFMANN, ULRICH WIESMANN, AND \\ NORBERT HERSCHKOWITZ
}

Department of Pediatrics, University of Berne, Berne, Switzerland

\begin{abstract}
Summary
Theophylline, a drug used in neonatology for the treatment of apnea, affects cholesterol synthesis if administered in concentrations of $10^{-4} \mathrm{M}$ (a concentration found in serum of treated patients) for $24 \mathrm{hr}$ to dissociated brain cell cultures. The ratelimiting enzyme of cholesterol synthesis, $\beta$-hydroxy- $\beta$-methylglutaryl-coenzyme A reductase (EC 1.1.1.34), is lowered to $45 \% 48 \mathrm{hr}$ after removal of theophylline. At the same time, cholesterol content of the cells is lowered to $73 \%$. Inasmuch as the phospholipid content of the cells remains stable, the treatment changes the cholesterol phospholipid ratio. Concomitant to this effect, the activity of cerebroside-sulfotransferase (EC 2.8.2.11) is lowered to $60 \%$ of control values. We postulate that these two effects are linked to each other by means of modulation of the cerebrosidesulfotransferase activity by membrane lipids.
\end{abstract}

\section{Speculation}

Theophylline reduces cholesterol synthesis and content and by that cerebroside-sulfotransferase activity in dissociated brain cell cultures. This raises the question of whether theophylline could have similar effects in vivo.

Theophylline and its derivatives have been used in perinatal medicine for the treatment of asphyxia in premature newborns ever since Úany et al. (19) could demonstrate in 1975 the beneficial effects of theophylline on severe primary apnea in premature infants. Recently, Allan and Volpe (1) reported that theophylline and aminophylline reversibly inhibit the cholesterol synthesis in rat glioblastoma cells $\left(\mathrm{C}_{6}\right)$. The inhibition of cholesterol synthesis in brain cells by theophylline would be of special importance because the brain has to synthesize its cholesterol de novo (9). Dietary cholesterol does not penetrate the blood brain barrier. Cholesterol is a major lipid component of all brain cell membranes and especially of the myelin sheath (3, 18). In addition, the cholesterol and the phospholipid content in brain microsomes are involved in the regulation of enzyme activities important for the synthesis of myelin lipids during myelination (14, 17). In mouse brain microsomes, the developmental change of the cholesterol: phospholipid ratio modulates the activity of cerebroside-sulfotransferase [(CST) EC 2.8.2.11] so that it shows an age-dependent developmental pattern (17). CST catalyses the transfer of a sulfate group to cerebroside forming sulfatide, an acidic sphingolipid which is an important component of myelin $(5,13)$.

Changing the cholesterol content of glioblastoma $C_{6}$ cells in culture by estradiol results in a modulation of CST activity by changing the cholesterol:phospholipid ratio in the Golgi apparatus $(15,16)$.

Because the influence of theophylline on the brain cholesterol metabolism and its secondary effects on myelin lipid synthesis is

${ }^{1}$ Dedicated to Andrea Prader on the occasion of his 60th birthday. difficult to study in whole animal experiments, we have studied the effect of theophylline in dissociated brain cell cultures as a first step. This culture model is closer to the in vivo situation than the $C_{6}$ tumor cells. Brain cell cultures have previously been used to study drug effects $(2,7)$.

In the present study, we investigated whether theophylline inhibits $\beta$-hydroxy- $\beta$-methyl-glutaryl-coenzyme $A$ reductase [(HMG CoA reductase) EC 1.1.1.34], which is a key enzyme in cholesterol synthesis, whether this inhibition is followed by a reduction of cellular cholesterol content, and whether we can observe an effect on CST activity.

\section{MATERIALS AND METHODS}

Dissociated brain cells were prepared from newborn mice (Jack River Albino) after a method described previously $(2,21)$. Mouse brains were removed within $2 \mathrm{hr}$ after birth, dissected in Dulbecco's modified Eagle medium at room temperature, minced with razor blades, dissociated by trituration, and incubated in Petri dishes (diameter, $10 \mathrm{~cm}$ ) with $10 \mathrm{ml}$ of Eagle's modified Dulbecco medium at $\mathrm{pH} 7.4,37^{\circ} \mathrm{C}, 80 \%$ relative humidity. Cell cultures were gassed with $5 \% \mathrm{CO}_{2}, 40 \% \mathrm{O}_{2}$, and $55 \% \mathrm{~N}_{2}$. Ten percent fetal calf serum $(\mathrm{v} / \mathrm{v})$ was present in the media. After 4,7 , and 10 days in culture, the medium was changed. At day $13,10^{-4}$ $M$ theophylline (Sigma Chemical Co., St. Louis, MO) were added in $10 \mathrm{ml}$ of medium and left for $24 \mathrm{hr}$. Then the theophylline was removed by changing the medium, and the cells were incubated for another $24 \mathrm{hr}$ in medium which again contained $10 \%$ fetal calf serum. Plates were analyzed immediately before theophylline administration ( $0 \mathrm{hr}$, after removal of theophylline $(24 \mathrm{hr})$, and 24 $\mathrm{hr}$ after removal of the drug $(48 \mathrm{hr})$. The cells were harvested with a rubber policeman after washing twice in situ with $10 \mathrm{ml}$ cold $0.9 \% \mathrm{NaCl}$ solution. The cells were centrifuged and resuspended in saline three times, finally suspended in $1 \mathrm{ml}$ bidistilled water, and homogenized by sonication for $30 \mathrm{sec}$ at $0^{\circ} \mathrm{C}$ with a Branson sonifier.

\section{HMG COA REDUCTASE ASSAY $(10,14)$}

One hundred $\mu$ of the homogenate containing 200 to $300 \mu \mathrm{g}$ protein were preincubated with $2 \mu$ moles NADPH (Boehringer Mannheim) in $30 \mu \mathrm{l} \mathrm{H}_{2} \mathrm{O}$ and $100 \mu \mathrm{l}$ phosphate buffer, $250 \mathrm{mM}$ (pH 7.2) for $10 \mathrm{~min}$ at $37^{\circ} \mathrm{C}$. After $10 \mathrm{~min} 1$ to $2(100,000 \mathrm{dpm})$ nmoles of $\beta$-hydroxy- $\beta-\left[{ }^{14} \mathrm{C}\right]$ methylglutaryl-coenzyme A $(51.3$ $\mathrm{mCi} / \mathrm{mmole}$ ) in $30 \mu \mathrm{l} \mathrm{H}_{2} \mathrm{O}$ were added, and the incubation was carried out for $1 \mathrm{hr}$ at $37^{\circ} \mathrm{C}$ in a total volume of $260 \mu \mathrm{l}$. To stop the reaction and to accomplish the formation of mevalonolactone from the product, $40 \mu \mathrm{l}$ of $6 \mathrm{~N} \mathrm{HCl}$ were added, and the mixture was shaken for another $30 \mathrm{~min}$. Then, $1 \mathrm{mg}$ of mevalonolactone (Fluka, Buchs, Switzerland) was added as a carrier, and the incubates was washed with $1 \mathrm{ml}$ of cold benzene. After centrifugation, $50 \mu \mathrm{l}$ of the aqueous layer were spotted on a thin-layer chromatography plate (Merck, Darmstadt Germany) and devel- 
oped in benzene:acetone (1:1). The chromatography was stopped after the solvent front was $10 \mathrm{~cm}$ above the start, and the spots with an $R_{F}$ value of 0.48 to 0.58 were scraped out, transferred to a counting vial, and counted after addition of $10 \mathrm{ml}$ Aquassure (New England Nuclear, Dreieich, Germany) in a Packard liquid scintillation counter. The results are expressed as pmoles mevalonolactone formed per $\mathrm{hr}$ and $\mathrm{mg}$ protein.

\section{CST ASSAY}

CST was assayed as described elsewhere with the following modifications (17): $100 \mu \mathrm{l}$ of protein suspension $(200$ to $300 \mu \mathrm{g}$ protein), $200 \mu \mathrm{l}$ of imidazole buffer $(100 \mathrm{mM}$, containing $20 \mathrm{mM}$ $\mathrm{MgCl}_{2}$ and $200 \mathrm{mM} \mathrm{NaCl}$ ), 450,000 dpm 3',5' diphosphoadenosyl $5^{\prime}$-sulfate (specific activity, $1 \mathrm{mCi} / \mathrm{mmole}$ ) in $100 \mu 10.9 \% \mathrm{NaCl}$ solution, and $0.1 \%$ Triton $\mathrm{X}-100$ (total volume $500 \mu \mathrm{l}$ ) were incubated for $20 \mathrm{~min}$ at $30^{\circ} \mathrm{C}$ at $\mathrm{pH} 6.8$. The incubation was stopped by addition of $4 \mathrm{ml}$ chloroform:methanol (2:1) separated in two phases with $1.2 \mathrm{ml}$ of $0.74 \% \mathrm{KCl}$. The upper phase was discarded, and the lower phase was washed twice with theoretical upper phase (chloroform:methanol:water, 4:48:47), transferred to a counting vial, dried with a hair dryer, and counted after addition of $10 \mathrm{ml}$ Aquassure in a liquid scintillation counter. The addition of Triton instead of deoxycholate (17) did not solubilize the enzyme protein from the membrane, as checked by centrifugation for $90 \mathrm{~min}$ at $100.000 \times \mathrm{g}$, but allowed higher protein concentrations in the assay.

Both of the enzyme reactions were linear with protein up to 500 $\mu \mathrm{g} / \mathrm{ml}$ and with time up to $90 \mathrm{~min}$.

\section{LIPIDS}

Lipids were extracted from the cell cultures after the method of Folch-Pi et al. (6). Cholesterol content was determined after the method of Zlatkis et al. (22). Phospholipids were analyzed as total lipid phosphorus after Donaldson et al. (4) and protein after Lowry et al. (11).

Sulfatide was checked by thin-layer chromatography as the only lipid containing radioactive sulfate in the CST assay.

\section{RESULTS}

The standard experiments were performed as described in "Materials and Methods." The effect of theophylline on HMG CoA reductase activities is shown in Table 1.

The enzyme activities of the control cultures increased up to the end of the experiment whereas in the test cultures, the activity remained constant. Thus, a significant progressive decrease of the relative activity occurs in theophylline-treated cultures even after removal of the drug.

Table 2 summarizes the results of the protein, cholesterol, and phospholipids content in treated and untreated cultures. Throughout the observation period, cholesterol content of the cultures decreases. However, in theophylline-treated cultures, the lowering of cholesterol content is more rapid; therefore, a significantly lower cholesterol content is found after the $24 \mathrm{hr}$ of drug exposure and during the $24-\mathrm{hr}$ recovery period. There is no consistent change in phospholipid and protein content. Because of the changes of the cholesterol content, the molar cholesterol:phospholipid ratio is significantly reduced at the end of the drug exposure and $24 \mathrm{hr}$ thereafter.

The results of the determination of the CST activity in test and control cultures are shown in Table 3 . Whereas CST activity in control cultures remains stable during the observation period, in theophylline-treated cultures the CST activity falls after the $24 \mathrm{hr}$ incubation and reaches a value of $58 \%$ that of controls after the recovery period.

Table 1. Activity of $\beta$ HMG CoA reductase (EC 1.1.1.34) in dissociated mouse brain cell cultures treated with $10^{-4} \mathrm{M}$ theophylline

Table 1. Activily of $\beta$ for $24 \mathrm{hr}^{1}$

\begin{tabular}{|c|c|c|c|c|c|}
\hline Days in culture & $\mathrm{Hr}$ after inoculation & & $\begin{array}{c}\text { HMG CoA reductase activity } \\
\text { (pmoles mevalonate } / \mathrm{mg} \text { protein } \times \mathrm{hr} \text { ) }\end{array}$ & $P^{2}$ & $\%$ of controls \\
\hline 13 & 0 & $\begin{array}{l}\text { Theophylline added } \\
\text { (control) }\end{array}$ & $36.6 \pm 7.93^{3}$ & & 100 \\
\hline 14 & 24 & $\begin{array}{l}\text { Control } \\
\text { Theophylline with- } \\
\text { drawn }\end{array}$ & $\begin{array}{l}35.38 \pm 2.89 \\
22.33 \pm 2.52\end{array}$ & $<0.05$ & $63 \pm 4$ \\
\hline 15 & 48 & $\begin{array}{l}\text { Control } \\
\text { Recovery period }\end{array}$ & $\begin{array}{l}42.67 \pm 6.50 \\
19.17 \pm 3.32\end{array}$ & $<0.001$ & $45 \pm 8$ \\
\hline
\end{tabular}

'For details of incubation and experimental design, see "Materials and Methods."

$2 P$ 's were calculated as Student's $t$ tests of normal and control plates.

${ }^{3}$ Means \pm S.D. of 3 determinations with 2 plates.

Table 2. Cholesterol, phospholipid, and protein content of dissociated brain cell cultures treated with $10^{-4} \mathrm{M}$ theophylline for $24 \mathrm{hr}$

\begin{tabular}{|c|c|c|c|c|c|c|}
\hline Days in culture & $\mathrm{Hr}$ after inoculation & & $\begin{array}{c}\text { Protein } \\
\text { (mg/plate) }\end{array}$ & $\begin{array}{c}\text { Cholesterol } \\
\text { ( } \mathrm{g} / \mathrm{mg} \text { protein })\end{array}$ & $\begin{array}{l}\text { Phospholipids } \\
\text { ( } \mu \mathrm{g} / \mathrm{mg} \text { protein) }\end{array}$ & $\begin{array}{l}\text { Molar choles- } \\
\text { terol:phospho- } \\
\text { lipid ratio }\end{array}$ \\
\hline 13 & 0 & $\begin{array}{l}\text { Theophylline added } \\
\text { (control) }\end{array}$ & $3.15 \pm 0.0^{2}$ & $39.97 \pm 3.4$ & $256.88 \pm 4.62$ & $0.29 \pm 0.02$ \\
\hline 14 & 24 & $\begin{array}{l}\text { Control } \\
\text { Theophylline with- } \\
\text { drawn }\end{array}$ & $\begin{array}{l}2.78 \pm 0.62 \\
3.08 \pm 0.06^{3}\end{array}$ & $\begin{array}{l}43.77 \pm 2.76 \\
34.18 \pm 3.03^{4}\end{array}$ & $\begin{array}{l}266.33 \pm 15.37 \\
303.61 \pm 17.21^{: 3}\end{array}$ & $\begin{array}{l}0.33 \pm 0.02 \\
0.23 \pm 0.04^{4}\end{array}$ \\
\hline 15 & 48 & $\begin{array}{l}\text { Control } \\
\text { Recovery period }\end{array}$ & $\begin{array}{l}3.46 \pm 0.47 \\
3.76 \pm 0.55^{3}\end{array}$ & $\begin{array}{l}33.51 \pm 1.59 \\
26.83 \pm 1.73^{4}\end{array}$ & $\begin{array}{l}244.33 \pm 30.37 \\
232.33 \pm 22.50^{3}\end{array}$ & $\begin{array}{l}0.27 \pm 0.02 \\
0.22 \pm 0.01^{5}\end{array}$ \\
\hline
\end{tabular}

'Incubation conditions and determination of the lipids were as described in "Materials and Methods." The cholesterol:phospholipid ratio was calculated from each of two single plates. As a basis for the calculation of the molar ratios, the molecular weight of cholesterol was taken as 387 , and for the phospholipids, an average value of 775 was assumed.

"Mean \pm S.D. of 3 experiments of two plates each.

"Not significant according to Student's $t$ test.

${ }^{4} P<0.05$ according to Student's $t$ test.

" $P<0.001$ according to Student's $t$ test. 
Table 3. Activity of CST (EC 2.8.2.1I) in dissociated mouse brain cell cultures treated with $10^{-4} \mathrm{M}$ theophylline for $24 \mathrm{hr}$

\begin{tabular}{|c|c|c|c|c|c|}
\hline Days in culture & Hr after inoculation & & $\begin{array}{c}\text { CST activity } \\
\text { (pmoles sulfatide mg protein } \times \mathrm{hr} \text { ) }\end{array}$ & $P^{2}$ & $\begin{array}{l}\text { CST activity in \% of } \\
\text { controls }\end{array}$ \\
\hline 13 & 0 & $\begin{array}{l}\text { Theophylline added } \\
\text { (control) }\end{array}$ & $201 \pm 37^{3}$ & & \\
\hline \multirow[t]{2}{*}{14} & \multirow[t]{2}{*}{24} & Control & $176 \pm 14$ & \multirow[t]{2}{*}{$<0.001$} & \\
\hline & & $\begin{array}{l}\text { Theophylline with- } \\
\text { drawn }\end{array}$ & $120 \pm 6$ & & 68 \\
\hline \multirow[t]{2}{*}{15} & \multirow[t]{2}{*}{48} & Control & $172 \pm 3$ & \multirow[t]{2}{*}{$<0.001$} & \\
\hline & & Recovery period & $99 \pm 9$ & & 58 \\
\hline
\end{tabular}

'For details of incubation and experimental design, see "Materials and Methods."

$2 P$ 's are calculated as Student's $t$ tests of normal and control plates.

${ }^{3}$ Mean \pm S.D. of 3 determinations. For the calculations of pmoles sulfatide, the specific activity of the added $3^{\prime}, 5^{\prime}$ diphosphoadenosyl-5'-sulfate was used, assuming that it was not diluted by endogenous precursor. The values are corrected for a lipid-protein ratio of 0.35 , as indicated elsewhere (15). This ratio was found in control plates if the medium is changed daily.

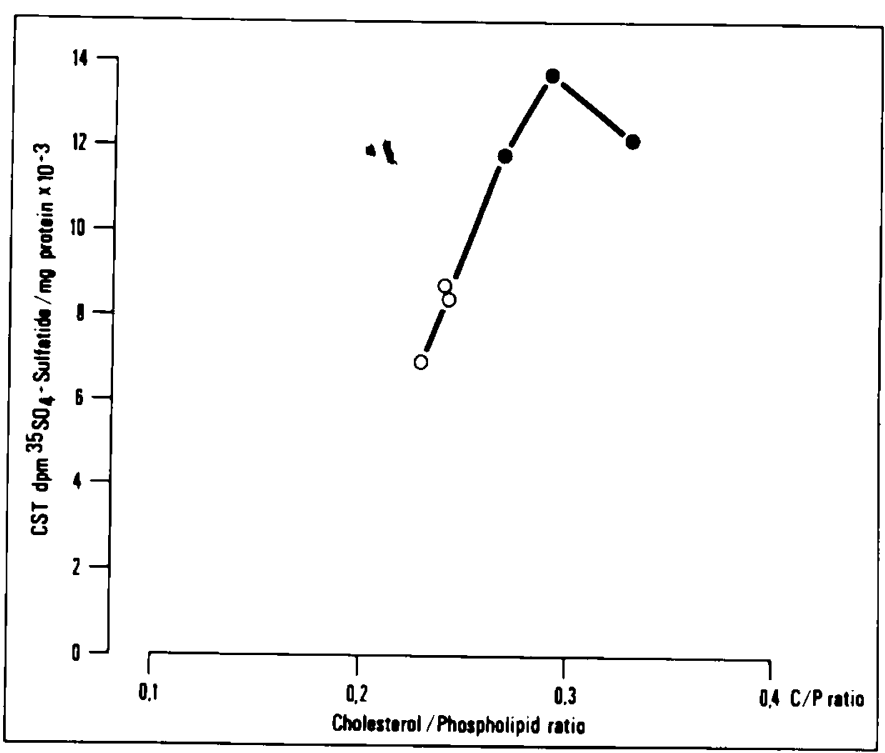

Fig. I. Comparison of the cholesterol:phospholipid ratio with the CST activity as extracted from Tables 2 and 3. $O$, values after treatment with $10^{-4} \mathrm{M}$ theophylline for $24 \mathrm{hr}$; 9 , control values. For details, refer to Tables 2 and 3 .

\section{DISCUSSION}

Theophylline in concentrations of $10^{-4} \mathrm{M}$ added to the medium in brain cell cultures for $24 \mathrm{hr}$ reduces HMG CoA reductase activity to $63 \%$. No recovery was observed within $24 \mathrm{hr}$ after removal of theophylline. Control experiments adding $10^{-4} \mathrm{M}$ theophylline directly to the enzyme assay had no effect on the HMG CoA reductase activity. These results are in accordance with the observation of Allan and Volpe (1), who studied the effect of theophylline on the activity of $C_{t i}$ cells in culture. Concomitant to the reduced enzyme activity, the cholesterol content of the membranes decreases to $78 \%$ during the $24-\mathrm{hr}$ incubation. This decreased cholesterol content in the treated cells remains constant for the $24 \mathrm{hr}$ recovery period compared to the controls. The decreased cholesterol content leads to a significant decrease in the cholesterol:phospholipid ratio $24 \mathrm{hr}$ after the incubation and does not reach control values again during the recovery period.

During the period of decreased cholesterol:phospholipid ratio, CST activity drops to $68 \%$ and $58 \%$, respectively. Again, control experiments adding $10^{-4} \mathrm{M}$ theophylline directly to the enzyme assay had no effect on the enzyme activity. Plotting CST activity against cholesterol:phospholipid ratio (Fig. 1) in normal and treated cells suggests that CST activity is modulated by the changed cholesterol:phospholipid ratio. A dependence of CST activity on the cholesterol:phospholipid ratio has been previously shown in microsomes of mouse brain during development (17), in correction experiments of the decreased CST activity in jimpy (12) brain microsomes (8), and in $\mathrm{C}_{6}$ cells in culture treated with estradiol (15).

Theophylline is known to affect fatty acid and cholesterol synthesis (20). We have now shown that CST activity is also affected. We have to stress, however, the fact that the system used does not allow us to answer the question of whether the decreased CST activity has an effect on myelination. It will, therefore, be of importance to expand the brain cell culture experiments to the in vivo development because in brain cell cultures only few myelination occurs.

\section{REFERENCES AND NOTES}

I. Allan. W. C., and Volpe. J. J.: Methylxanthines cause a marked reduction in cholesterol synthesis in cultured glial cells. Pediatr. Res., 12: 401 (1978).

2. Amonn, F., Baumann, U.. Wiesmann. U. N., Hofmann. K.. and Herschkowitz. $\mathrm{N}$. .: Effects of antibiotics on the growth and differentiation in dissociated brain cell cultures. Neuroscience, 3: 465 (1978).

3. Bourre, J. M.. Pollet, S. A., Daudu, O. L.. and Baumann, N. A.: Evolution, in mouse brain microsomes, of lipids and their constituents during myelination. Brain Res., 51: 225 (1973).

4. Donaldson. R. P.. Tolbet. N. F.. and Schnorrenberger. C.: An improved method of phospholipid determination. Arch. Biochem. Biophys., 152:199 (1972).

5. Farooqui, A. A.. Rebel, G., and Mandel. P.: Sulphatide metabolism in brain. Life Sci., 20: 569 (1977).

6. Folch-Pi. J., Lees, M., and Solane Stanley, G. M.: A simple method for the isolation and purification of total lipids from animal tissues. J. Biol. Chem..
226: 497 (1957).

7. Johnston, D., Webster. K. C., Chittoor, K. R., and Melnykovych. G.: Cholesterol biosynthesis in a variety of cultured cells. Lack of correlation between synthesis and activity of 3-hydroxy-3-methylglutaryl coenzyme $A$ reductase caused by dexamethasone. Biochim. Biophys. Acta, 572: 188 (1979).

8. Jutzi, H., Siegrist. H. P., Burkart, T.. Wiesmann, U., and Herschkowitz, N. N.: Diminished cerebroside-sulfotransferase activity in the jimpy mouse mutant due to altered lipid composition in microsomal membranes. Biochim. Biophys.
Acta, 5.52: 413 (1979).

9. Kabara, J. J.: A critical review of brain cholesterol metabolism. Prog. Brain Res.. 40: 379 (1973).

10. Kandutsch, A. A., and Saucier. S. E.: Sterol and fatty acid synthesis in developing brains of three myelin-deficient mouse mutants. Biochim. Biophys. Acta, 260: $26(1972)$.

11. Lowry, O. H., Rosebrough, N. J., Farr, A. L., and Randall, R. J.: Protein measurement with the Folin phenol reagent. J. Biol. Chem., 193: 265 (1951).

12. Meier. C.: Die Maus-Mutante "Jimpy". Fortschr. Med., 43: 2623 (1977).

13. Pilz. H.: Clinical morphological and biochemical aspects of sphingolipidoses. Neuropaediatrie. 1: 383 (1969).

14. Sabine, J. R., and James, M. J.: The intracellular mechanism responsible for dietary feedback control of cholesterol synthesis. Life Sci., /8: 1185 (1976).

15. Siegrist, H. P.. Burkart. T., Hoffmann, K., Wiesmann, U., and Herschkowitz, N. Influence of reduced cholesterol synthesis on the activity of cerebroside sulfotransferase in cultured glioblastoma cells treated with estradiol. Biochim. Biophys. Acta, 572: 160 (1979).

16. Siegrist, H. P., Burkart. T.. Wiesmann, U. N., Herschkowitz, N. N., and Spycher. M. A.: Diminished cerebroside-sulfotransferase activity in the jimpy mouse mutant due to altered lipid compocontinuous sucrose gradient of mouse brain microsomes. J. Neurochem., 33: 497 (1979).

17. Siegrist, H. P., Jutzi. H., Steck. A. J., Burkart, T., Wiesmann, U., and Herschkowitz. N.: Age-dependent modulation of 3 '-phosphoadenosine- 5 '-phosphosulfate-galactosylceramide sulfotransferase by lipids extracted from the microsomal membranes and artificial lipid mixtures: Biochim. Biophys. Acta, 489: 
58 (1977).

18. Spohn. M., and Davison. A. N.: Cholesterol metabolism in myelin and other subcellular fractions of rat brain. J. Lipid Res., 13: 563 (1972).

19. Úańy, R., Shapiro, D., and Smith. D.: Effect of theophylline on severe primary apnea of prematurity: a preliminary report. Pediatrics, 55: 595 (1975).

20. Volpe. J. J., and Marasa. J. C.: Long-term regulation by theophylline of fatty acid synthetase, acety!-CoA carboxylase and lipid synthesis in cultured glial cells. Biochim. Biophys. Acta, 431: 195 (1976).

21. Wiesmann, U. N., Hofmann, K.. Burkart, T., and Herschkowitz, N.: Dissociated cultures of newborn mouse brain. Neurobiology (Copenh.). 5: 305 (1975). 22. Zlatkis, A., Zak, B., and Boyle, A. J.: A new method for cholesterol determination: J. Lab. Clin. Med., 41: 486 (1963).

23. Requests for reprints should be addressed to: Dr. Hans Peter Siegrist. Kinderklinik, Inselspital, Freiburgstrasse, 3010 Berne. Switzerland

24. This research was supported by Grants 3.419 .78 and 3.768 .76 of the Swiss National Science Foundation.

25. Received for publication October 2, 1979.

26. Accepted for publication January 23,1980

Copyright (c) 1980 International Pediatric Research Foundation. Inc 